\title{
Floral Marketing and Consumer Research
}

\author{
Bridget K. Behe \\ Department of Horticulture and Alabama Agricultural Experiment Station, 101 Funchess Hall, \\ Auburn University, AL 36849-5408
}

Global floral consumption is more than \$25 billion/year (de Boon, 1990), and the United States ranked 12th of 15 countries in per capita floral consumption (Eurofloratech, 1991). The market is expanding and lucrative. Marketing terminology and concepts are appearing more often in horticultural literature as researchers attempt to understand the floral industry and business managers face greater competition. Some consumer and market research in floriculture has been published, but much more is needed (Armitage, 1986). The objective of this article is to summarize published floricultural market and consumer research.

Kotler (1984) defined marketing as the tasks engaged in by an organization to determine and meet the needs of targeted groups while balancing the organization's profits and the groups' interests. He described the history of marketing from its foundation in 17th century Japan, when a member of the Mitsui family opened the first department store in Tokyo (Kotler, 1984). He further described that, in the United States, marketing was formally initiated in the business sector when The Curtis Publishing Co. established a commercial research department. After World War II, modem marketing techniques were adopted on a larger scale by many companies. Smith (1956) first defined the important yet practical concepts of market segmentation and product targeting that are still considered fundamental to management strategies today.

Floricultural market research could be characterized as either market or consumer research. Market research describes industry characteristics and trends, while consumer research focuses on consumer characteristics and behavior. Floral market research has been limited to production statistics, while some investigation of retail marketers has been conducted. Early floral consumer behavior studies examined the demographic characteristics of individuals who purchased the flowers. More recent floral consumer research has used multivariate computer analytic techniques to describe multiple attributes of floral products and the reasons for product purchase and/ or use.

\section{MARKET RESEARCH}

Floral products are a product category that contains flowering and foliage plants and fresh-

\footnotetext{
Received for publication 18 Feb. 1992. Accepted for publication 1 July 1992. Alabama Agricultural Experiment Station no. 11-923240. The cost of publishing this paper was defrayed in part by the payment of page charges. Under postal regulations, this paper therefore must be hereby marked advertisement solely to indicate this fact.

'Assistant Professor.
}

cut flowers and greens. Flowering plants may include annual and perennial bedding plants and traditional florist crops in various pot sizes. Difficulty in defining product categories, infrequent data collection, and inadequate funding of statistical collection and dissemination of research results have produced limited production information.

Wholesale value of domestic floral crop production for 28 states was $\$ 2.77$ billion in 1990 (U.S. Dept. Agriculture, 1991), up 10\% from 1989. Somewhat enhanced information is published less frequently in the Census of Horticultural Specialties (U.S. Dept. Commerce, 1989a, 1989b), which lists production of specific plant genera, and in the Statistical Review (Johnson and Napper, 1989). The floral industry, once dominated by domestic production, is now a global one, with a significant proportion of fresh flowers produced in Colombia and the Netherlands for export to the United States and other markets (Staby and Robertson, 1982). The wholesale value of imported fresh-cut floral products and greens was \$305 million in 1988 (Johnson and Napper, 1989), while wholesale domestic production that year was \$571 million. Difficulty in tracking production growth increases when data collection changes, thus prohibiting long-term trend analysis.

Floral products were traditionally marketed through many small, vertically integrated retail florist firms (Sullivan et al., 1980). In the 1950s grocery stores began selling annual bedding plants to alleviate seasonal surpluses experienced by local growers (Goodrich, 1980). Sales of floral products through mass merchandisers, especially supermarkets, have steadily increased since that time, and now mass merchandisers are perceived by many in the floral industry as the strongest competitors of retail florists (Buckley, 1982).

The supermarket floral retailer has been studied extensively (Baker and Goodrich, 1968; Goodrich, 1980; Kiplinger and Sherman, 1962; Kress, 1973, 1983, 1986, 1987; Robertson and Hahn, 1978; Russell Marketing Research, 1990; Sherman and Baker, 1960; Vance Publishing Corp., 1989). Early studies focused on the types of products sold and seasonal sales trends (Baker and Goodrich, 1968; Kiplinger and Sherman, 1962; Sherman and Baker, 1960). Recent research showed that nearly all supermarkets sell floral products on a regular or seasonal basis, with many mass merchandisers targeting self- or low-service products by merchandising prepackaged bouquets and blooming and foliage plants (Kress, 1987; Vance Publishing Corp., 1989). Some supermarkets have begun to upgrade the level of customer service provided to consumers by offering design, delivery, wedding packages, and wire service capabilities (Kress, 1987; Vance Publishing Corp., 1989), thus positioning themselves to compete with traditional florists directly.

Regional differences in merchandising strategies among traditional florists in the nine U.S. Dept. of Agriculture regions were identified (Behe et al., 1987). Pacific region florists (Washington, Oregon, California) spent less on advertising than florists in other regions yet had higher cash-and-carry sales. East northcentral florists (Wisconsin, Michigan, Ohio, Indiana, Kentucky) spent more on advertising and had higher telephone sales than other regional florists. Differences between singleand multiple-location florists were characterized (Behe and Prince, 1985). Multiple-shop firms generated lower revenues per store, had fewer full-time employees and walk-in customers, and spent less per store for Yellow Pages advertising than single-shop firms. Floral franchise outlets have been successful on a regional basis, while others have expanded nationally (Sulecki, 1991).

Holness (1985) identified three segments of retail florists' advertising and promotional strategies using cluster analysis. Nineteen percent of the florists (291 of 1520) were classified as Type I, which were relatively large, established, urban, multiple-location firms that relied heavily on cash-and-carry sales. In contrast, 26\% were identified as Type II florists that were younger, smaller, less urban, singlelocation firms that relied more on customerinitiated telephone sales. The majority, 55\%, were Type III florists-relatively new, singlelocation firms that relied heavily on telephone sales. Type I florists used all forms of advertising media extensively, spent more on advertising and promotion, and used direct mail advertising more than Type II or III florists. Type II florists used electronic media more, including radio and television, and spent more on advertising than Type III florists, who relied heavily on traditional print media, which included Yellow Pages and newspaper advertising.

Customers perceive marketers differently by the level, quality, and types of services offered (Zeithaml et al., 1990), and floral marketers experienced a similar reaction. Prince et al. (1990a) identified product quality maintenance, order/delivery reliability, and product availability as the three most important services a floral supplier can provide for a floral retailer. They showed a difference in service perceptions between traditional florists and floral mass merchandisers in terms of product quality maintenance, product availability, and communications/order information (Prince et al., 1990b). I found no research on consumer perceptions of and satisfaction with floral retailing services. 


\section{CONSUMER RESEARCH}

In consumer research, single-variable demographic characteristics are often correlated with purchase patterns, partly due to the ease of measuring demographic characteristics such as age and income. Floral purchases increase as income increases (de Boon, 1990; Prince and Prince, 1991; R.T. Kelley, Inc., 1983; Sherman et al., 1956; Soc. Amer. Florists, 1989; Zawadzki et al., 1960). Age is also positively correlated with floral purchasing, but it peaks at about age 45 and then declines (Behe and Wolnick, 1991a; Crispell, 1991; de Boon, 1990; Prince and Prince, 1991). Employment outside the home, related to household income, was also positively related to the number of floral purchases (Behe and Wolnick, 1991a). Demby (1973) analyzed men and women separately without determining behavioral differences, yet some evidence shows that floral purchase behavior varies by gender (Behe and Wolnick, 1991b; Prince and Prince, 1992b; Soc. Amer. Florists, 1989). Matsuo (1990) showed that there are differences by nationality.

Some research describes consumer preferences for floral products and product attributes. One of the first published floral consumer behavior studies was conducted in 1956 at Ohio State Univ. (Sherman et al., 1956). Most consumers on the panel preferred roses over carnations or chrysanthemums and preferred red over yellow or white flowers. Hutchison and Robertson (1979) determined that men preferred red roses over other colors, women preferred colors other than red, and both groups preferred pink least. Robertson and Chatfield (1982) found that nonred roses enhanced floral arrangement marketability. They (1981) also determined that nonhomogeneous colors in flower bunches were more appealing than homogeneous colors. Wolnick (1983) found that consumers preferred red geraniums over other colors. He did not determine whether this preference for red flowers created a demand for them or whether it reflected the dominance of red geraniums in commercial production schedules. Herrmann and Voigt (1988) showed that $46 \%$ (257 of 558) of consumer households in a Philadelphia and Washington, D.C., sample had purchased a poinsettia for Christmas in 1985 and that 79\% of those were red.

Robertson and Chatfield studied factors other than flower color (1981). They found that consumers selected fresh flower arrangements primarily by price and secondarily by composition. The container was relatively unimportant in their selection. When they examined preferences in arrangement style, Robertson and Chatfield found that roses arranged informally had the greatest appeal (1981). Consumers selected loose bunches of fresh flowers not by price but by composition. According to Prince et al. (1980), roses merchandised in units of five and nine had greater marketability than the traditional dozen. Thompson (1983) showed that while fresh flowers in the workplace did not affect employee attitude positively or negatively, the participants' ambivalence may have been due partly to the flower giver's lack of sentiment for the recipient.

Supermarket floral customers have been surveyed and profiled more often than other floral consumer groups (Behe, 1985; Goldsberry et al., 1985; Kelly, 1961; Kiplinger and Sherman, 1962; Miller, 1977; Perry, 1990; Prince and Prince, 1992a, 1992b; Rhodus, 1989; Zawadzki et al., 1960). Rhodus (1989) showed that supermarket floral bouquet purchases were price-elastic. Miller (1977) determined attitudes of supermarket floral customers about past purchases and future intentions. Accordingly, consumers did not patronize one type of store exclusively; rather, $53 \%$ of the consumers purchased from more than one retailer. He suggested that supermarketsand traditional florists may be serving the same consumer population. Levitt (1988) suggested that consumers may belong to more than one consumer segment, depending on their situation.

While analyses that correlate individual variables provide useful information, multivariate analyses enable more sophisticated investigation. Prince and Prince (1992a, 1992b) have labeled a multivariate analytic technique as "Product/Value Analysis" and showed that supermarket consumers value chrysanthemum price and color over flower form and care instructions. Additional research on the floral purchase process and level of satisfaction with the purchase can be investigated with multivariate techniques.

In two studies, market segments were developed using cluster analysis (Behe et al., 1992b; Soc. Amer. Florists, 1989). Smith (1956) developed the concepts of market segmentation and product targeting. Marketing theory suggests that a segmentation strategy enables management to allocate scarce resources more efficiently while achieving a profit (Kotler, 1984). Behe et al. (1992b) divided supermarket customers into five segments based on factors that affect floral purchase decisions (1992a). "Friendly buyers" were young consumers with relatively low annual household incomes who purchased flowers as gifts for theircoworkers and mothers but made few purchases for themselves. "Married men" were somewhat older males who purchased flowers as gifts for their wives. "Selfers," the largest segment, frequently purchased flowers for personal use, and price was very important to them. "Annuals" purchased flowers only once each year, usually from the supermarket, for home decoration. The "educated mothers" segment was comprised of older, upper-income women who bought floral products mainly during holidays associated with meals: Thanksgiving, Easter, and Christmas, These consumer segments were similar to those identified in Market Facts, Inc.'s study (Soc. Amer. Florists, 1985) of floral consumers. They used a panel of men and women and identified five segments: plant people, flower people, givers, selfers, and special occasion only.

Another market segment study (Behe and Wolnick, 1991a) found few differences be- tween consumers who purchased primarily potted plants and consumers who purchased primarily fresh-cut flowers. It appeared that consumers purchased products depending on the situation, not on the individual's characteristics. This conclusion was consistent with Levitt's hypothesis that consumers may belong to more than one segment (1988).

Volume segmentation divides a consumer market by purchase frequency, a procedure that has been used successfully in other markets (Kotler, 1984). The conceptual basis for volume segmentation is that consumers who purchase a product more frequently differ in additional aspects from consumers who purchase the product less frequently. Rather than increasing the total number of consumers in the market, managers who use a volume segmentation seek to expand the market by increasing the total number of purchases per consumer. Marketing theory states that it is easier to have a current consumer make an additional purchase than to solicit a new consumer (Kotler, 1984).

Consumers who purchase more of a product have been considered to be more involved with that product than consumers who purchase less of it. Product involvement has been discussed extensively in marketing literature, and several authors have captured the essence of the arguments (Bloch and Richins, 1983; Gutman, 1982; Sujan, 1985; Zaichkowsky, 1986). Product involvement can be defined as the degree of personal relevance an object has for an individual. Means-end chains can be used to diagram conceptually the degree of personal relevance (Gutman, 1982). A technique in which a consumer is led to chain ideas together would begin with a concrete product attribute (flower color) chained to more abstract constructs such as functional outcomes (flower color becoming part of an interior decor), then to psychological outcomes (which creates a pleasant atmosphere), and perhaps to personal values (creating personal satisfaction). As the chain becomes more highly developed, the consumer becomes more involved with the product. Smaller or less developed chains would indicate little personal relevance andlittle product involvement. Longer chains, with more abstract constructs, indicate a higher degree of personal relevance and more product involvement. Light users likely have shorter means-end chains than heavy users.

The focus of the consumer's involvement is also important. Product involvement is often discussed in general, unfocused terms. The consumer can be involved in finding and buying the product (search and selection), and/or involved in its use, or the consumer can show an enduring or intrinsic involvement with the product, as a hobbyist would. Product selection, purchase, and use can influence intrinsic involvement with the product. Heavy consumers would likely be more involved with product search, selection, and purchase than light consumers. If products are frequently given as gifts, the consumer may not be heavily involved with product use. Intrinsic involvement should be higher for a heavy consumer than a light consumer. 
In highly developed markets, $85 \%$ of people buy flowers at least once per year, while in a poorly developed market, only $42 \%$ buy flowers (de Boon, 1990). Purchase frequency varies from fewer than 15 times per year in an underdeveloped market to 15 to 20 times per year in a highly developed market (de Boon, 1990).

Behe and Wolnick (1991b) concluded that the heaviest consumers of floral products were likely to be relatively affluent and purchase floral products for their own use and as traditional gifts. In contrast, light floral consumers were less affluent and more likely to purchase floral products for traditional gift reasons or obligatory purchases, such as funeral flowers, with few personal-use purchases. Segmenting the market for floral consumers by flower purchase frequency was a feasible alternative to segmenting the market by demographics.

Market Facts, Inc. (Soc. Amer. Florists, 1989) reported a trend in floral consumption for personal use. Although data were collected in a cross-sectional panel study, some implications were made related to a longitudinal trend. This study indicated that an individual passes through four levels or phases as floral consumption frequency increases. At the first level, no floral products are purchased. At level two, flowers are purchased as gifts on special occasions and events with few personal plant purchases. At level three, a consumer purchases more plants for personal use while maintaining or increasing floral gift purchases. In the final level, a high proportion of floral gift purchases are made along with regular plant and some flower purchases for personal use.

Of increasing interest is the use of flowers after purchase, categorized as either gifts or personal use. The percentage of floral products used as gifts is relatively high on most holidays and special occasions (Behe and Wolnick, 1991b; Gallup Organization, 1990). Belk's (1976, 1979, 1982) theoretical conceptualization of gift-giving applies to floral purchasing and giving. His work outlined giver-gift-recipient interactions. Gift-giving performs symbolic communication in that the gift acts as both the channel of a message and the message itself. Situational and geographic/ cultural influences and the degree of intimacy between giver and recipient affect the gift selection process. Although some industry members believe that the market for gift flowers has matured, the role of flowers as a versatile yet unique gift needs further study.

Garbarino (1963) studied floral consumption in the early 1960s. He found that consumers most frequently purchased floral products as gifts for others, rather than for their own enjoyment. Scammon et al. (1982) applied gift-giving theory to understand situational influences on floral purchases, particularly when flowers were given away. The Gallup Organization (1990) showed that many considered flowers an ideal gift to give when feeling guilty or to receive from an admirer.

Not considered in the same manner as other "gifts," flowers for the bereaved have been an integral part of floral sales. A traditional role of floral products in our society has been in comforting the bereaved. Shoemaker and Relf
(1991) defined the role of flowers in the bereavement process. More than $60 \%$ of the participants had received flowers as a sympathy gesture when someone close had died. Funeral directors believe that flowers serve an integral role in the funeral ritual by comforting those affected by a death. In a related study, $83 \%$ of surveyed grief therapists indicated that flowers aid in the grieving process.

The floral industry is demanding intensified consumer and market research as other industries actively pursue consumer preferences and product/service needs to remain profitably competitive. As floral professionals realize an increasing need to understand the floral purchaser, more research-based information should be commissioned. There is a significant body of literature, funded by private interests, beyond publicly accessible information. Crop production information, while necessary to track market growth and development, is insufficient in determining how best to meet consumer desires. Consistent measurement of crop production and importation needs to be funded to follow the most fundamental growth of the industry.

Mass-market retailing of floral products revolutionized the industry by exposing more consumers to floral products on an everyday basis. Franchising, successful in some markets, could also change how and where people buy flowers. Nontraditional outlets, such as greeting-card stores, toll-free phone numbers, and mail-order catalogs, may further increase consumer exposure to floral products.

More research is needed to understand many facets of the floral consumer: Who purchases flowers; who receives them; who enjoys them; how flowers are selected, purchased, and delivered; and why flowers are purchased over other products and services. A better understanding of the purchase process and satisfaction with the purchase and product/service mix is important to developing the floral marketing industry. Gift-giving theory can be used to understand when flowers are appropriate gifts or self-indulgences. Plant breeders and commercial producers would benefit from understanding the importance of flower attributes (i.e., flower and plant fragrance, color, and form) relative to price. Investigating personal use-flowers bought for the buyer rather than as a gift-and commercial use of flowers may help develop the nongift floral market.

Market and consumer research involving floral products has been published since 1956 . Advanced computer technology and sophisticated statistical analyses, although underused, have increased the amount of floral consumer and market research tremendously. Much of this research pertains to describing the floral consumer and the floral retailer at a surface level. Interactions of consumer characteristics and prediction of consumer purchase behavior and satisfaction remain to be studied.

\section{Literature Cited}

Armitage, A.M. 1986. Evaluation of new floricultural crops: A systems approach. HortScience 21:9-11.
Baker, M. and DC. Goodrich. 1968. Flower retailing by mass outlets. N.J. Agr. Expt. Sta. Bul. 817, Rutgers Univ., New Brunswick, N.J.

Behe, B.K. and T.L. Prince. 1985. Marketing mix characteristics of single and multiple locations florists. HortScience 19:560.

Behe, B.K., T.A. Prince, and H.K. Tayama. 1992a. Analysis of consumer purchases of floral products in supermarkets. HortScience 27:455-459.

Behe, B.K., T.A. Prince, and H.K. Tayama. 1992b. Market segmentation of supermarket floral customers. HortScience 27:459-462.

Behe, B.K., T.L. Prince, W.T. Rhodus, and J.L. Robertson. 1987. Regional differences in retail floral merchandising strategies. Acta Hort. 203:157-163.

Behe, B.K. and D.J. Wolnick. 1991a. Type of floral product purchased and demographic characteristics and floral knowledge of consumers. HortScience 26:414-416.

Behe, B.K. and D.J. Wolnick. 1991b. Market segmentation of Pennsylvania floral consumers by purchase volume and primary retail outlet. HortScience 26:1328-1331.

Belk, R.W. 1976. It's the thought that counts: A signed digraph analysis of gift-giving. J. Consumer Res. 3:155-161.

Belk, R.W. 1979. Gift-giving behavior. Res. in Mktg. 2:95-126.

Belk, R.W. 1982. Effects of gift-giving involvement on gift selection strategies. Adv. Consumer Res. 9:408-411.

Bloch, P.H. and M.L. Richins. 1983. A theoretical model for the study of product importance perceptions. J. Mktg. 47:69-81.

Buckley, E. 1982. Supermarkets reach out for 6billion dollar floral market. Produce \& Floral Retailing 1:6.

Crispell, D. 1991. Targeting the American floral consumer. GrowerTalks 54:21-27.

de Boon, I.H. 1990. A world perspective on more flowers for more people. Professional Plant Growers Assn. News 21:7, 10-11.

Demby, E. 1973. A psychographic study of the market for flowers. Amer. Floral Mktg. Council, Alexandria, $\mathrm{Va}$

Eurofloratech. 1991. Norway consumption best in world. Eurofloratech March:6.

Gallup Organization. 1990. A Gallup study of American's gift-giving attitudes and behavior, revised. Gallup Org., Princeton, N.J.

Garbarino, A.J. 1963. Consumers' preferences for floral products in the Memphis market. Univ. of Tennessee Agr. Expt. Sta. Bul. 355, Knoxville.

Goldsberry, K.L., N. Baker, and M. Michaels. 1985. Determining the desires of supermarket cut flower customers: A six year evaluation. Colo. Agr. Expt. Sta. Res. Bul. 421, Fort Collins.

Goodrich, D.C., Jr. 1980. Floral marketing. Chain Store Publ., New York.

Gutman, J. 1982. A means-end chain model based on consumer categorization processes. J. Mktg. 46:60-72.

Herrmann, R.O. and A.O. Voigt. 1988. Marketing opportunities for Pennsylvania-grown poinsettias. Pa. Flower Growers Bul. 388:1-2.

Holness, P.A. 1985. A descriptive profile of the retail florist industry's advertising and promotional strategies. MS Thesis, Ohio State Univ., Columbus.

Hutchison, N.R. and J.L. Robertson. 1979. Consumer demand analysis for roses. J. Amer. Soc. Hort. Sci. 104:303-308.

Johnson, D.C. and W.P. Napper. 1989. Production and marketing of floriculture and environmental horticultureproducts: A statisticalreview, 196088. Commodity Econ. Div., Econ. Res. Serv., U.S. Dept. Agr., Washington, D.C. 
Kelly, R.A. 1961. Floricultural sales in mass market outlets. Univ. of Illinois Agr. Expt. Sta. Bul. 675.

Kiplinger, D.C. and R.W. Sherman. 1962. Florist crops for mass market outlets. Ohio Agr. Expt. Sta. Res. Bul. 928, Wooster.

Kotler, P. 1984. Marketing management: Analysis, planning and control. 5th ed. Prentice-Hall, Englewood Cliffs, N.J.

Kress, J.G. 1973. Mass marketing-A reassessment. Florists Rev. 152:19, 20, 56.

Kress, J.G. 1983. The floral movement. GrowerTalks 46:34-42.

Kress, J.G. 1986. Floral products in supermarkets. The Packer, Vance Publ. Corp., Shawnee Mission, Kan

Kress, J.G. 1987. Super survey. Soc. Amer. Florists 4:24-30.

Levitt, T. 1988. The pluralization of consumption. Harvard Business Rev. 88:7-8.

Matsuo, E. 1990. Analysis of flower appreciation and its international comparison contribute to progress of flower production and international flower trade. HortScience 25:1468-1471.

Miller, M.N. 1977. Consumer preferences for and attitudes toward cut flower items in supermarkets. MS Thesis, Purdue Univ., West Lafayette, Ind.

Perry, L.P. 1990. Vermont surveys track shifts in plant buyers' preferences. Greenhouse Manager 9:128

Prince, T.A. and T.L. Prince. 1991. State demographic trends shape consumer floral buying. Flower News 45:28

Prince, T.A. and T.L. Prince. 1992a. Consumers' mum-purchasing behavior revealed in tests. Floral Mass Mktg. 8(1):1, 5, 16

Prince, T.A. and T.L. Prince. 1992b. Value of mum longevity and care information revealed in Yoder tests. Floral Mass Mktg. 8(2):1, 5, 11.

Prince, T.L., J.L. Robertson, and L.H. Chatfield. 1980. Factors affecting the marketability of roses. J. Amer. Soc. Hort. Sci. 105:388-393.

Prince, T.L., H.K. Tayama, and J.R. Grabner, Jr. 1990a. Supplier services and their importance to floral retailers in the midwestem United States. HortScience 25:356-358.

Prince, T.L., H.K. Tayama, and J.R. Grabner, Jr. 1990b. Floral supplier service levels to retail florist and mass market customers. HortScience 25:689-692.

Rhodus, W.T. 1989. Estimating price elasticity for fresh flower bouquets sold in supermarkets. HortScience 24:386-387.

Robertson, J.L. and L.H. Chatfield. 1981. Analysis of fresh flower merchandising. Ohio Agr. Res. and Development Ctr., Res. Bul. 1136, Ohio Agr. Expt. Sta., Wooster.

Robertson, J.L. and L.H. Chatfield. 1982. Fresh flower merchandising in loose bunches. HortScience 17:593-595.

Robertson, J.L. and D.E. Hahn. 1978. Analysis of demand for potted chrysanthemums in supermarkets. J. Amer. Soc. Hort. Sci. 103:203-206.

R.T. Kelley, Inc. 1983. Flowers Canada Ontario. Consumer research: Final results. R.T. Kelley, Inc. Ontario, Canada.

Russell Marketing Research. 1990. Survey of supermarket floral retailing. 2nd Annu. Produce Mktg. Assn./Food Mktg. Inst. Survey Supermarket Produce Performance. Produce Mktg. Assn., Newark, Del.

Scammon, D.L., R.T. Shaw, and G. Bamossy. 1982. Is a gift always a gift? An investigation of flower purchasing behavior across situations. Adv. Consumer Res. 9:531-536.

Sherman, R.W. and M. Baker. 1960. Sale of potted plants and cut flowers through supermarkets,
Columbus, Ohio, 1955-1960. Ohio Agr. Expt. Sta. Bul. A.E. 315, Wooster.

Sherman, R.W., D.C. Kiplinger, and H.C. Williams. 1956. Consumer preferences for cut roses, carnations, chrysanthemums. Ohio Agr. Expt. Sta. Res. Circ. 31, Wooster.

Shoemaker, C.A. and P.D. Relf. 1991. Flowers for funerals-They are important. Res. Rpt. Amer. Floral Endowment, Edwardsville, Ill. 2:1-4.

Smith, W.R. 1956. Product differentiation and market segmentation as alternative marketing strategies. J. Mktg. 21:3-8.

Soc. Amer. Florists. 1985. Society of American Florists floral marketing report. Market Facts, Soc. Amer. Florists, Washington, D.C.

Soc. Amer. Florists. 1989. Society of American Florists floral marketing report. Market Facts, Soc. Amer. Florists, Washington, D.C.

Staby, G.L. and J.L. Robertson. 1982. International movement of cut flowers. HortScience 17:729733.

Sujan, M. 1985. Consumer knowledge: Effects on evaluation strategies mediating consumer judgements [sic]. J. Consumer Res. 12:31-46.

Sulecki, J.C. 1991. Hallmark test yielding mixed results. Greenhouse Grower 9:80-84.

Sullivan, G.H., J.L. Robertson, and G.L. Staby. 1980. Management for retail florists. W.T. Freeman, San Francisco.
Thompson, J.L. 1983. The effectiveness of flowers as a change element in the office environment on the attitudes of employees. MS Thesis, Ohio State Univ., Columbus.

U.S. Department of Agriculture. 1991. Floriculture crops 1990 summary. Natl. Agr. Stat. Serv., Agr. Stat. Brd., Sp Cr 6-1(91), Washington, D.C.

U.S. Department of Commerce. 1989a. 1987 Census of agriculture. vol. 1. Geographic Area Ser. AC87-A-51. Bur. Census, Washington, D.C.

U.S. Department of Commerce. 1989b. 1987 Census of agriculture. vol. 4. Census Hort. Specialties (1988), AC87-HOR-1. Bur. Census, Washington, D.C.

Vance Publishing Corp. 1989. Fresh trends, shopping for flowers and plant products: Profiling the supermarket floral consumer. The Packer, Vance Publishing Corp., Lincolnshire, Ill.

Wolnick, D.J. 1983. Consumer preference studies with zonal geraniums. Flor. Rev. 162:31-33.

Zaichkowsky, J.L. 1986. Conceptualizing involvement. J. Advertising 15:4-14.

Zawadzki, M.I., W.E. Larmie, and A.L. Owens. 1960. Selling flowers in supermarkets. Rhode Island Agr. Expt. Sta Res. Bul. 355, Kingston.

Zeithaml, V.A., A. Parasuraman, and L.L. Berry. 1990. Delivering quality service: Balancing customerperceptions and expectations. The Free Press, Macmillan, New York.

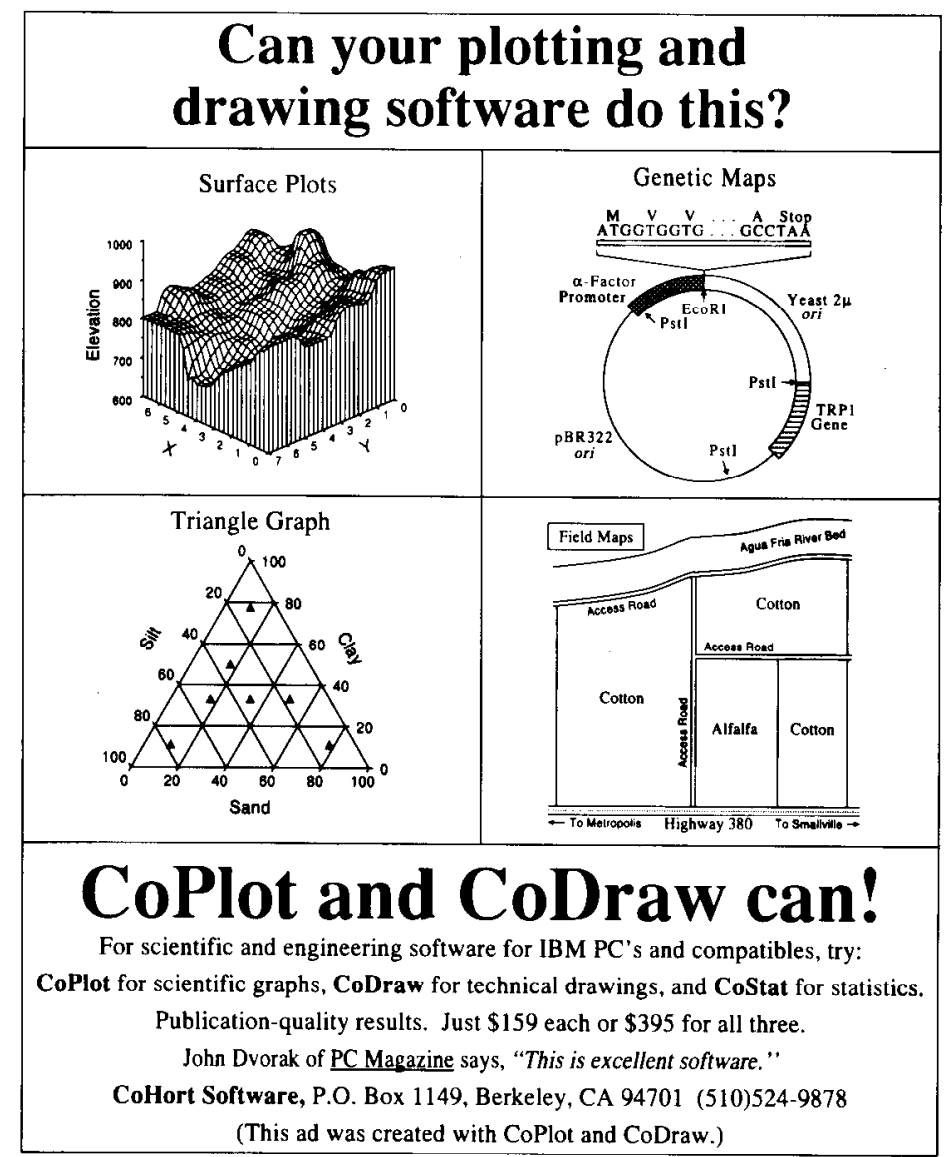

